Pediat. Res. 8: 830-836 (1974)

Amino acids fetus glucose

\title{
Fetal Metabolic Response to Maternal Starvation
}

\author{
MICHAEL A. SIMMONS, GIACOMO MESCHIA, EDGAR L. MAKOWSKI, AND \\ FREDERICK C. BATTAGLIA ${ }^{(32)}$ \\ Division of Perinatal Medicine, Departments of Pediatrics, Physiology, and Obstetrics-Gynecology, \\ University of Colorado Medical Center, Denver, Colorado, USA
}

\section{Extract}

In the pregnant ewe in the fed state, higher maternal protein intake does not lead to increased protein catabolism by the fetus. Total maternal starvation results in a prompt fall in fetal glucose concentrations (by $35 \%$ ) to a stable plateau by $48 \mathrm{hr}$ of starvation. Transplacental glucose uptakes during prolonged starvation are less than $\mathbf{4 0} \%$ of normal fed state values. Fetal urea production rates (a reflection of amino acid catabolism) increase to a level twice the fed state values by the 4th day of starvation and then return to base-line values by the 7 th day of starvation. Fetal glucose concentrations remain stable throughout prolonged starvation, even after urea production rates have returned to base-line values.

\section{Speculation}

At the peak of urea production, amino acid catabolism by the fetus can account for at least $80 \%$ of fetal oxygen consumption. However, the mechanisms and substrates available for homeostasis during the first 2 days (and after the 7 th day of starvation) are unknown and, in the face of depressed transplacental glucose uptakes, may put the fetus at significant risk.

Traditionally, glucose has been regarded as the primary energy substrate supplied to the fetus by the mother $(5,20)$, but the evidence for this view has been largely inferential. It has been assumed that a constant high level of glucose supply is required during fetal life for normal growth and development, and indeed for survival. Additional support for this hypothesis came from the observations of a very low urea excretion rate in newborn infants and thus, by extrapolation, a low urea production during fetal life (15).

Direct measurements of glucose and oxygen uptakes have only recently been possible in chronic, unstressed fetal sheep preparations. By such direct measurements of uptake, James et al. (12) have shown that glucose catabolism accounted for less than $50 \%$ of fetal sheep oxygen consumption in the last month of gestation. Furthermore, this study showed that glucose carbon would account for only one-quarter of the total carbon uptake by the fetus. Fructose has been shown to make no contribution to fed state catabolism (21). Although speculation continues about the contribution of fatty acids to fetal energy metabolism $(18,22,23)$, James et al. have shown that the umbilical uptake of free fatty acids (chain length $>\mathrm{C}_{5}$ ) and glycerol does not contribute significantly to the pool of catabolic substrate in the fetal sheep. In addition, Gresham et al. (8) have now shown that fetal sheep have a significant urea production rate while the mother is in the fed state, and that up to $25 \%$ of fetal oxygen consumption could be accounted for by amino acid catabolism.

The human fetus may have a similar metabolic pattern after maternal overnight fasting. Under such conditions, at cesarian section, the glucose/oxygen quotient in the human fetus is 0.81 (16), and there is a significant concentration difference of urea between fetal and maternal blood, which implies a significant urea production rate (10).

The now classic studies of Cahill and co-workers $(3,4,6,7$, 17), have demonstrated the complex hormonal-fuel interrelations in the adjustment to starvation by man. Similar data concerning the fetal response to starvation are not available. However, it has been shown that in starvation transplacental glucose uptake in sheep falls significantly, so that less than $20 \%$ of fetal oxygen consumption can be accounted for by glucose catabolism (2). In early starvation fructose makes no net contribution to fetal catabolism (21).

Significant clinical problems, in particular a high perinatal mortality rate (14), continue to exist in infants with intrauterine growth retardation. It is of great interest to identify the mechanisms available to the fetus for adjustment to conditions of undernutrition, whether secondary to maternal, fetal, or placental abnormalities. The present study investigates the time sequences and substrates involved in the fetal metabolic response to maternal starvation.

\section{METHODS}

\section{SURGERY AND ANIMAL MAINTENANCE}

Eight Western breed ewes with gestations of 110-125 days were starved for $48 \mathrm{hr}$ before surgery. Under intravenous pentobarbital sedation and Pontocaine spinal anesthesia, polyvinyl catheters of appropriate size were placed in a fetal hind limb vein and artery (a), and a maternal femoral artery (A). The catheters were led subcutaneously to a flank pouch. Procaine penicillin $(600,000$ units) and streptomycin $(1 \mathrm{~g})$ were administered intramuscularly on the day of surgery and for the first 3 postoperative days. The animals recovered promptly from surgery, and were standing in their individual pens, eating, and drinking within $6 \mathrm{hr}$. The catheters were flushed daily with a heparinized saline solution (40 units heparin/cc solution).

\section{DESIGN OF STUDY}

The first three animals were maintained on a diet in routine use in our animal quarters, consisting of alfalfa hay and Trophy horse ration grain supplement (25), which supplied approximately $2 \mathrm{~g}$ protein $/ \mathrm{kg} / 24 \mathrm{hr}$. The other five animals were maintained exclusively on a dehydrated alfalfa pellet (26) 
diet (guaranteed approximate analysis $17 \%$ protein) which could be quantitatively controlled, and supplied $3-5 \mathrm{~g}$ of protein $/ \mathrm{kg} / 24 \mathrm{hr}$.

After a minimal 5-day period to allow recovery from operative stress, a control stable metabolic state was defined in the following manner: repeated measurements of glucose and urea concentrations in simultaneous samples of maternal and fetal arterial blood were made until a stable base line for both glucose and urea concentrations was obtained. This implied, then, a stable concentration difference between the two arterial streams for both solutes. At this time, total starvation was instituted; the ewes allowed only water ad libitum. Frequent determinations of glucose and urea concentrations were made throughout the starvation period. Starvation was continued until delivery of the lamb or catheter failure.

Autopsies were performed in all animals killed before delivery. Fetal weights were obtained in all animals, as well as maternal weights at various times during the fed state and starvation.

\section{BIOCHEMICAL DETERMINATIONS}

Blood specimens of fetal and maternal arterial blood were separated into two $0.3-\mathrm{ml}$ aliquots and centrifuged in a microcentrifuge for $45 \mathrm{sec}$.

Glucose was measured on plasma approximately $10 \mathrm{~min}$ after drawing the specimen by a modification of the glucose analyzer (27) glucose oxidase method. This modification allowed increased sensitivity by increasing the volume of plasma used in the determination from $10 \mu \mathrm{l}$ to $50 \mu \mathrm{l}$ and standardizing the readings against standards pertinent to the range of concentrations encountered in maternal and fetal sheep blood. No metabolic inhibitor was added to the blood for glucose determinations.

The Beckman glucose analyzer method measures only the $\beta$ isomer of glucose. If only the $\beta$-glucose isomer crossed the placenta (and this is unlikely), there is the possibility that the concentration of glucose in the fetal blood would be overestimated. Figure 1 demonstrates the time course of the equilibration of $\beta$-glucose, as determined by the glucose analyzer method, after the addition of pure $\beta$-glucose at time zero. By $10 \mathrm{~min}$, approximately $80 \%$ of eventual equilibration is completed. In addition, only the umbilical arterial blood (a) (that is the placental inflow stream) glucose concentration was measured in this study, so complete $(\beta \rightleftarrows \alpha)$-glucose equilibration is a fair assumption. It should be emphasized that when glucose uptake is determined (Fig. 7), the umbilical venous and umbilical arterial glucose concentrations must both be measured on whole blood, and after complete equilibration of $(\beta \rightleftarrows \alpha)$-glucose has occurred. (In our methodology, $2 \mathrm{hr}$ are allowed to elapse.)

Urea was measured on plasma (EDTA added to blood) by the blood-urea-nitrogen analyzer (27) urease method. Urea was calculated from the blood-urea-nitrogen readings of the analyzer by multiplying a factor of 2.14 (molecular weight urea/molecular weight $\mathrm{N}_{2}$ ).

Protein concentrations in all specimens were determined by a temperature-compensated hand refractometer (28) and recorded in grams per milliliters.

All concentrations of glucose and urea were converted to milligrams per $100 \mathrm{ml}$ plasma water by use of Equation 1

$$
\frac{\mathrm{mg} / 100 \mathrm{ml} \text { plasma }}{1-\text { protein }(\mathrm{g} / \mathrm{ml} \text { plasma })}=\mathrm{mg} / 100 \mathrm{ml} \text { plasma water }
$$

\section{UREA CLEARANCE MEASUREMENTS}

Placental urea clearance was determined in three animals. After base line determinations of fetal and maternal arterial urea concentrations were made, a urea solution of known concentration (approximately $40 \mathrm{~g} / 100 \mathrm{ml}$ ) was then infused,

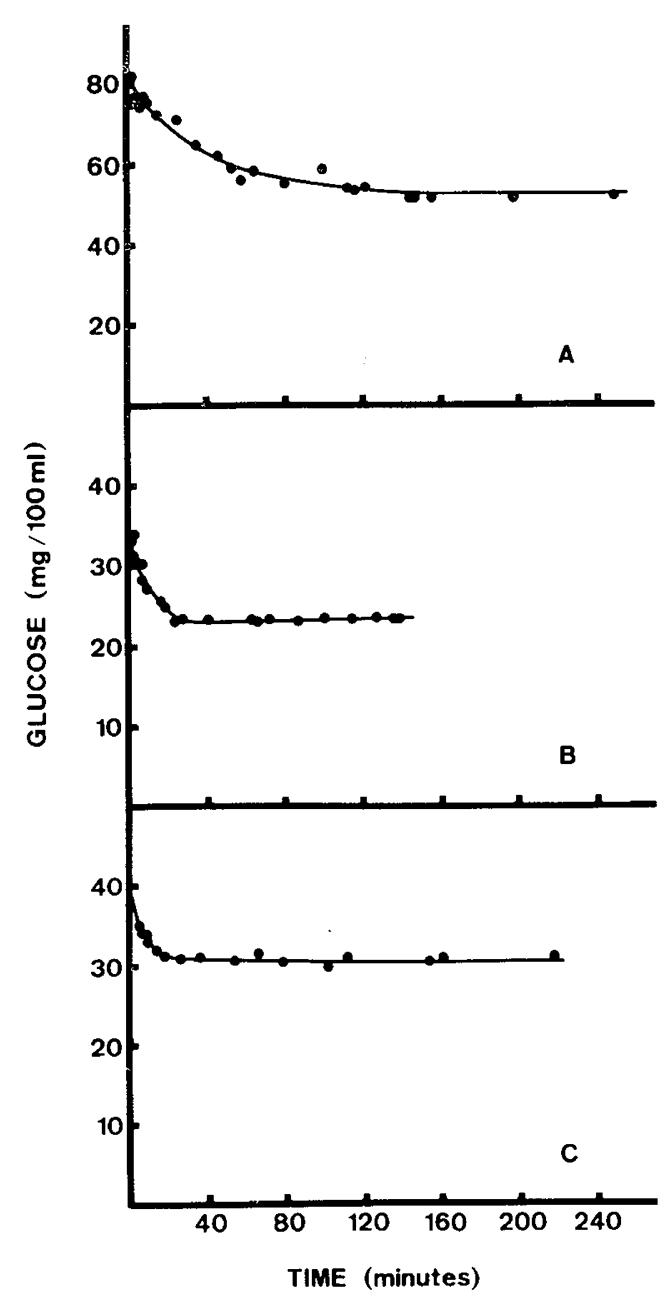

Fig. 1. Effect of $\beta \rightarrow \alpha$-glucose isomer conversion on the determination of glucose concentrations by the glucose oxidase method in $(A)$ saline solution, $(B)$ plasma, and $(C)$ whole blood. The pure $\beta$ isomer of glucose was added at time zero and glucose concentrations then determined at various times over the next 3-4 hr.

through a microfilter, into the fetal pedal vein with a constant infusion pump (29) at a rate of approximately $0.9 \mathrm{ml} / \mathrm{min}$ After $\sim 60-90$ min to allow equilibration of urea throughout fetal body water space, simultaneous samples of maternal and fetal arterial blood were obtained every $10-15$ min over $1-2$ $\mathrm{hr}$ for measurement of urea concentrations.

If the rate of infusion $\left(R_{I}\right)$ is known, the rate of transplacental diffusion of the exogenous urea $\left(R_{D}\right)$ can be calculated from Equation 2

$$
\mathrm{R}_{\mathrm{D}}=\mathrm{R}_{\mathrm{I}}-\mathrm{R}_{\mathrm{ACC}}-\mathrm{R}_{\mathrm{K}}
$$

The rate of fetal urea accumulation $\left(\mathrm{R}_{\mathrm{ACC}}\right)$ can be determined from the slope of the function of fetal arterial urea concentration versus time (Fig. 2). Total urea accumulation (milligrams per kilogram per minute) is obtained by the product of this slope (milligrams per milliliter per minute) and the fetal body water compartment $(800 \mathrm{ml} / \mathrm{kg})$.

The rate of fetal renal excretion of exogenous urea $\left(R_{K}\right)$ is calculated from fetal renal urea clearance (equal to $\sim 0.5$ $\mathrm{ml} / \mathrm{kg} / \mathrm{min}$ ) (19) multiplied by the fetal arterial concentration of urea at equilibrium $\left(\mathrm{a}_{\mathrm{eq}}\right)$ less the original fetal arterial urea concentration $\left(\mathrm{a}_{0}\right)$

$$
\mathrm{R}_{\mathrm{K}}=[\text { clearance urea }]_{\text {renal }} \cdot\left[\mathrm{a}_{\mathrm{eq}}-\mathrm{a}_{0}\right]_{\text {urea }}
$$

Placental clearance of urea is defined by Equation 4 


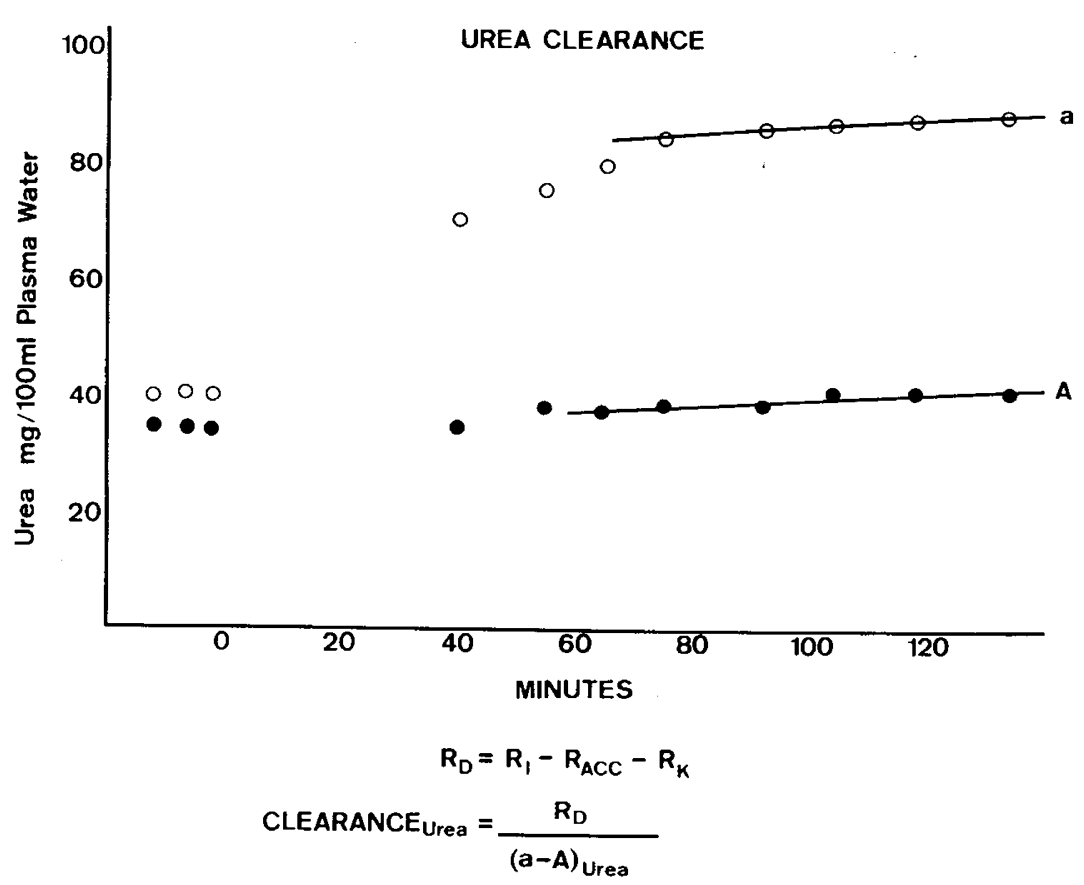

Fig. 2. Placental urea clearance. Concentrations of urea in fetal $(a)$ and maternal $(A)$ blood are plotted against the time of infusion of a known concentration of urea. After approximately $70 \mathrm{~min}$ a steady rate is reached, and regression lines are drawn through the $(a)$ and $(A)$ concentrations, with the midpoint of each line selected for determination of $a_{e q}$ and $\mathrm{A}_{\mathbf{e q}}$. See text.

Table 1. Experimental variables for individual animals

\begin{tabular}{|c|c|c|c|c|c|c|c|c|}
\hline $\begin{array}{c}\text { Animal } \\
\text { no. }\end{array}$ & $\begin{array}{l}\text { Gestational } \\
\text { age at } \\
\text { surgery, } \\
\text { days }\end{array}$ & $\begin{array}{c}\text { Maternal } \\
\text { fed- } \\
\text { weight, } \\
\mathrm{kg}\end{array}$ & $\begin{array}{l}\text { Days } \\
\text { starved }\end{array}$ & $\begin{array}{c}\text { Maternal } \\
\text { weight } \\
\text { loss, } \\
\text { kg }\end{array}$ & $\begin{array}{c}\text { Maternal } \\
\text { expected } \\
\text { weight } \\
\text { gain, } \mathrm{kg}^{1}\end{array}$ & $\begin{array}{c}\text { Fetal } \\
\text { weight, } \\
\mathrm{kg}\end{array}$ & $\begin{array}{c}\text { Fetal } \\
\text { weight } \\
\text { expected, } \\
\mathrm{kg}^{1}\end{array}$ & $\begin{array}{c}\text { Fetal } \\
\text { Outcome }\end{array}$ \\
\hline 1 & 115 & 60.0 & 17 & -10.0 & +6.0 & 3.2 & 4.3 & $\begin{array}{c}\text { Liveborn lamb, } \\
145 \text { days }\end{array}$ \\
\hline 2 & 125 & 55.5 & 7 & -5.9 & +2.5 & 3.3 & 4.3 & $\begin{array}{c}\text { Liveborn lamb, } \\
145 \text { days }\end{array}$ \\
\hline 3 & 115 & 51.4 & 9 & -6.8 & +3.2 & 3.4 & 3.8 & $\begin{array}{l}\text { Killed, catheter } \\
\text { failure }\end{array}$ \\
\hline 4 & 110 & 61.8 & 6 & -7.7 & +2.1 & 4.1 & 4.3 & $\begin{array}{l}\text { Killed, catheter } \\
\text { failure }\end{array}$ \\
\hline 5 & 110 & 55.0 & 12 & -10.0 & +4.2 & 3.3 & 3.8 & $\begin{array}{c}\text { Stillborn lamb, } \\
@ 141 \text { days }\end{array}$ \\
\hline 6 & 115 & 66.8 & 8 & -9.1 & +2.8 & 3.3 & 3.6 & $\begin{array}{c}\text { Liveborn lamb, } \\
@ 141 \text { days }\end{array}$ \\
\hline 7 & 120 & 80.5 & 16 & -13.6 & +5.6 & 3.2 & $3.8^{2}$ & Maternal death \\
\hline 8 & 125 & 52.7 & 9 & -6.8 & +3.2 & 3.8 & 4.6 & $\begin{array}{c}\text { Stillborn lamb, } \\
148 \text { days }\end{array}$ \\
\hline
\end{tabular}

${ }^{1}$ The difference between observed and expected fetal weights is significant at the $P=0.001$ level.

${ }^{2}$ Twin pregnancy; therefore expected weight may be overestimated.

$$
[\text { Clearance }]_{\text {urea }}=\frac{\left[\mathrm{R}_{\mathbf{D}}\right] \text { urea }}{\left(\mathrm{a}_{\text {eq }}-\mathrm{A}_{\text {eq }}\right) \text { urea }-\left(\mathrm{a}_{\mathbf{0}}-\mathrm{A}_{\mathbf{0}}\right) \text { urea }}
$$

where: $\mathrm{a}_{\mathrm{eq}}=$ fetal urea concentration at equilibrium; $\mathrm{A}_{\mathrm{eq}}=$ maternal urea concentration at equilibrium; $\mathrm{a}_{0}=$ fetal urea concentration before urea infusion; $A_{0}=$ maternal urea concentration before urea infusion.

\section{STATISTICAL METHODS}

Standard student $t$ test analyses were used to analyze differences between means in all cases. Paired $t$-tests were used to assess the significance of fetal weight retardation from expected weights (Table 1 ).

Regression lines were calculated by the least squares method.

\section{RESULTS}

\section{ANIMAL OUTCOME}

During the fed state, the ewes gained between 0.1 and 0.8 $\mathrm{kg} / 24 \mathrm{hr}$ (mean gain of $0.23 \mathrm{~kg} / 24 \mathrm{hr}$ ). As seen in Table 1, all ewes lost weight during starvation (mean loss $=0.88 \mathrm{~kg} / 24 \mathrm{hr}$, range $0.58-1.28 \mathrm{~kg} / 24 \mathrm{hr}$ ). This contrasts to the expected weight gain of $0.15-0.25 \mathrm{~kg} / 24 \mathrm{hr}$ during this phase of pregnancy as calculated from the data of Russel et al. (19).

There was one maternal death before delivery with no explanation at autopsy. Two ewes were killed before delivery because of catheter failure. There were two stillborn lambs, both near term, with no obvious cause of death. There were three liveborn lambs which, except for their small size, appeared healthy. 
All lambs were growth retarded in terms of weight (Table 1 ), with the most severe growth retardation generally in those animals which were starved the longest. The expected fetal weights were calculated as previously described (9).

\section{EFFECT OF DIET ON UREA AND GLUCOSE CONCENTRATIONS}

There was no difference, in the fed state, in glucose levels between the two different diet groups (routine protein intake versus enriched protein intake). There was a higher absolute urea concentration in both fetal and maternal blood in those animals fed the enriched protein diet. However, there was no difference between the diets in (a-A) urea difference. The implications of this observation will be discussed subsequently.

\section{EFFECT OF STARVATION ON UREA AND GLUCOSE}

Maternal starvation induced a prompt and significant fall in glucose concentrations in both maternal and fetal blood. Absolute urea concentrations (both a and A) increased to a peak between 2 and 4 days of starvation and then fell off slightly, but always remained above base line values. The typical pattern of maternal and fetal glucose and urea concentrations for one animal is shown in Figure 3.

The effect of starvation on fetal glucose concentrations is demonstrated in Figure 4 where the data (mean \pm SEM) from all eight animals are plotted against time of starvation. After stable fed state glucose concentrations over a 5-day period were documented (mean fed (a) glucose $=26.2 \pm 0.3 \mathrm{mg} / 100$ ml plasma water), starvation caused a prompt fall to a plateau after $48 \mathrm{hr}$ of starvation. All mean values in starvation are statistically different from the fed state mean, with a $P=0.02$ at $24 \mathrm{hr}$ of starvation. There is no significance to the difference between means after $48 \mathrm{hr}$.

In Figure 5 the pooled results from all eight animals demonstrate the effect of starvation on glucose (A-a) and urea (a-A) concentration differences. A stable fed state control period is again documented. Starvation causes a fall in the glucose (A-a) difference to a stable plateau after $48 \mathrm{hr}$ of starvation. All values in starvation are statistically different from the fed state, with a $P=0.02$ at $24 \mathrm{hr}$ of starvation.

Urea (a-A) differences increase to a peak between 3 and 4 days of starvation and return to fed state levels by seven days of starvation. There is no difference between the means in the fed state and the mean after 7 days of starvation. Urea (a-A) differences are significantly higher than fed state values between 2 days and 6 days of starvation, with $P$ values of 0.02 , $0.001,0.02$, and 0.02 .

\section{UREA CLEARANCE}

Figure 6 presents the data and calculated regression lines of placental urea clearance versus duration of starvation in each
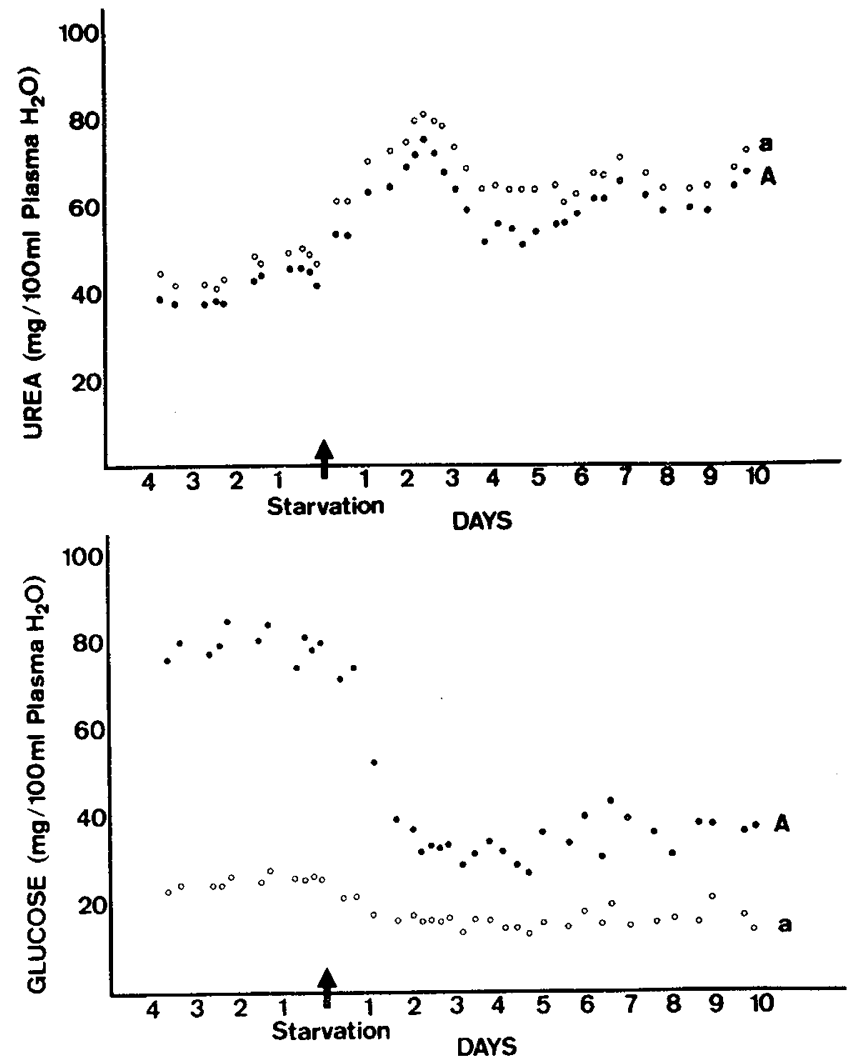

Fig. 3. The results in one typical animal of glucose and urea concentrations of fetal $(a)$ and maternal $(A)$ blood during the fed and starved states.

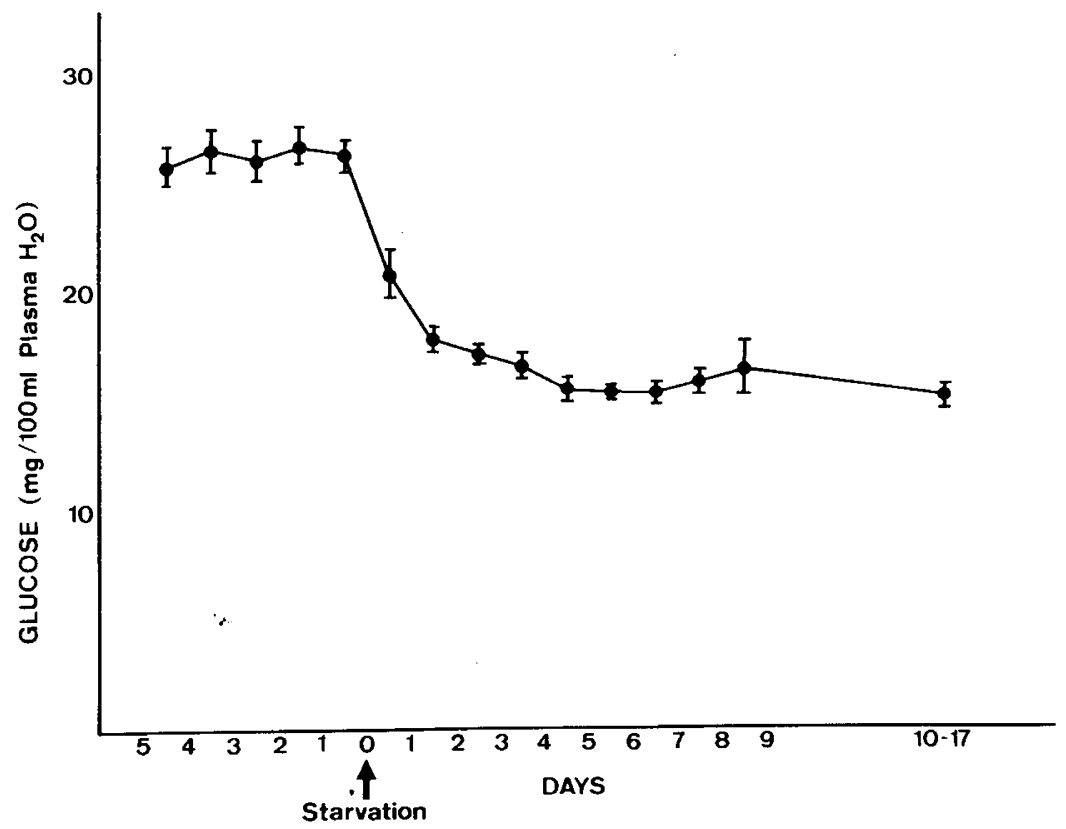

Fig. 4. Effect of starvation on fetal glucose. Mean fetal glucose concentrations $( \pm$ SEM) from all eight animals pooled. Individual values are averaged for 24-hr time period. After 2 days of starvation, there is no significant difference between means. 
of three study animals. Urea clearances were measured in the fed state and at least twice in starvation. At least four measurements of urea clearance were performed for each study period. Clearly there is no decrease in placental urea clearance with starvation.

\section{DISCUSSION}

Since the placenta is quantitatively the most important site of fetal urea excretion, fetal urea production can be estimated by Equation 5 . With a stable placental urea clearance, urea

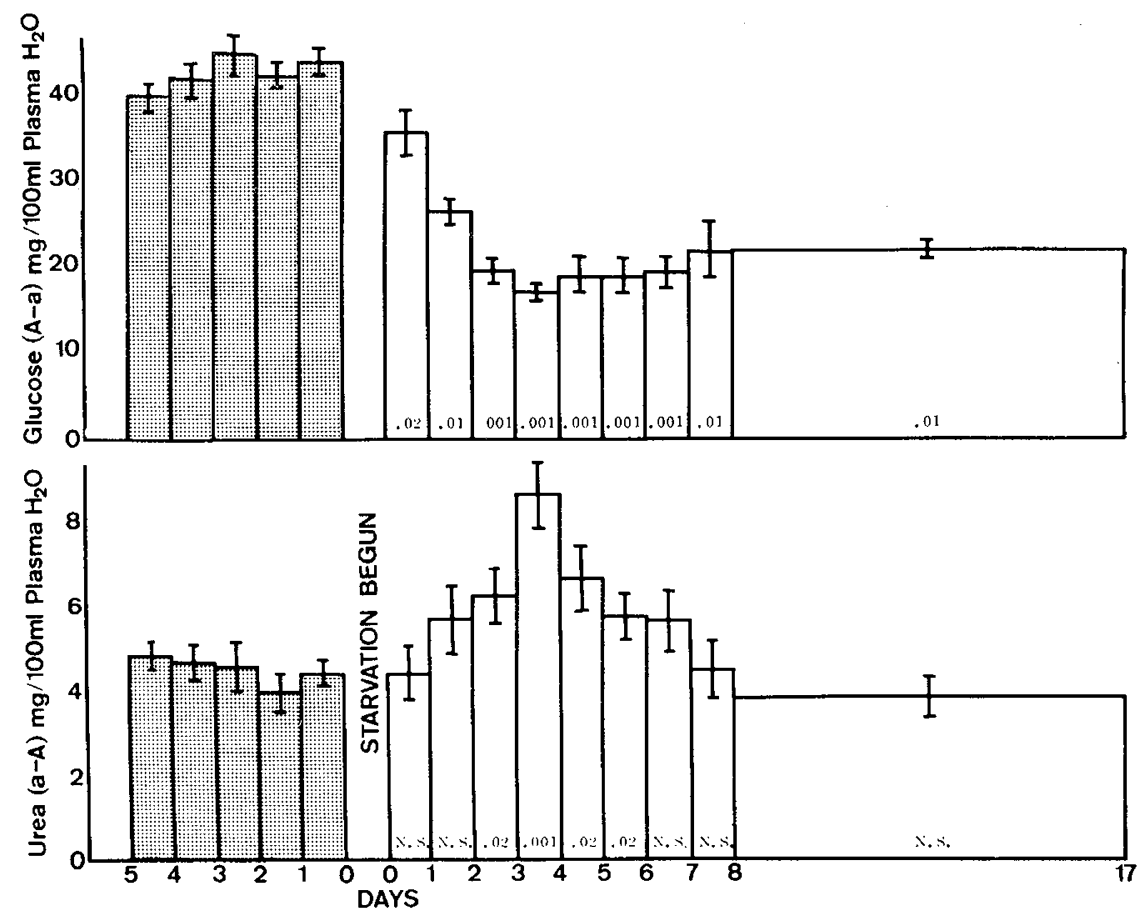

Fig. 5. Glucose (maternal $(A)$-fetal $(a)$ differences and urea (a-A) differences are plotted against days of starvation after a 5-day fed state with the significance levels of the observed value compared to the fed state mean recorded for each 24 -hr period. Glucose (A-a) differences are directly related to transplacental glucose uptakes and urea $(\mathrm{a}-\mathrm{A})$ differences are related to urea production by the fetus.

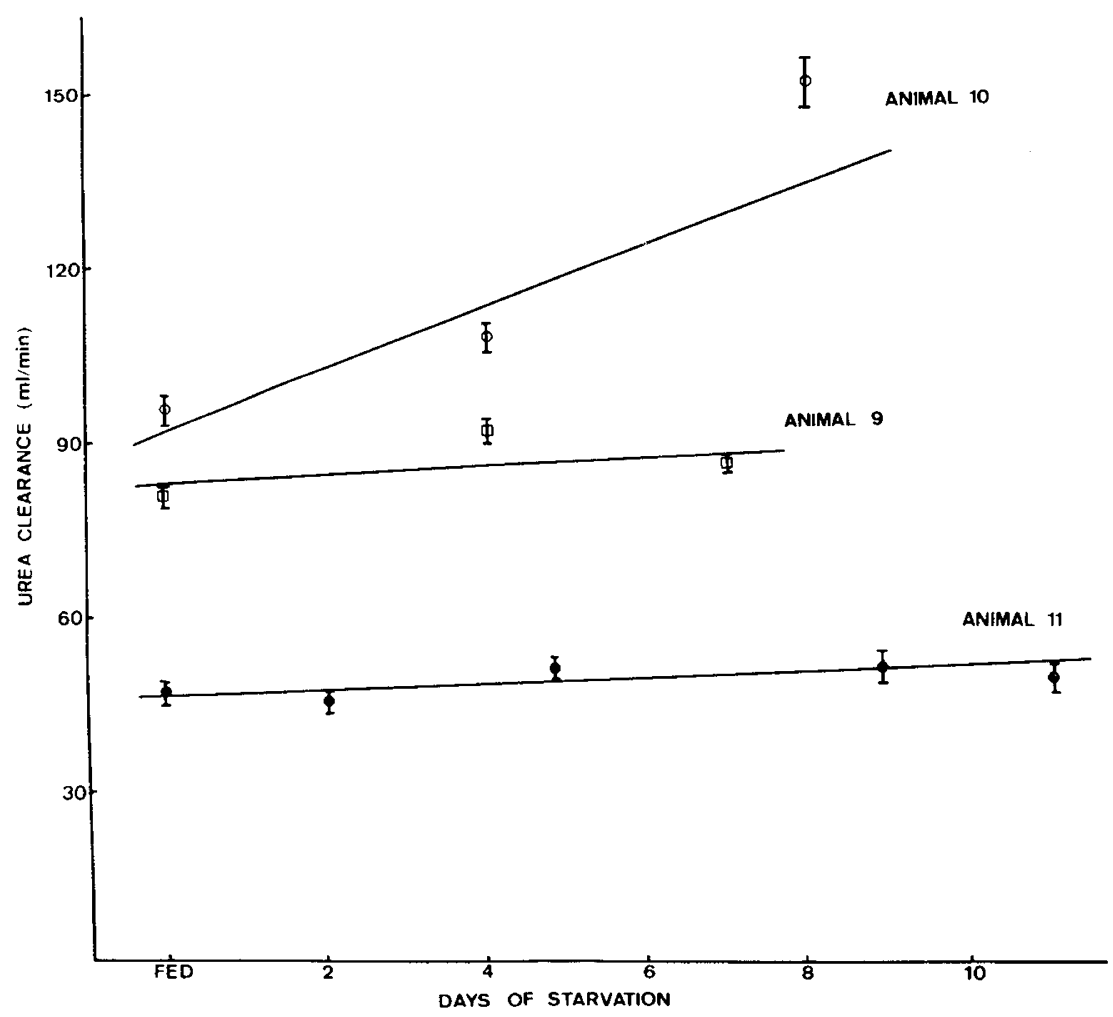

Fig. 6. Effect of starvation on urea clearance. Each regression line is a result of a minimum of 15 determinations of urea clearances during two to four study periods in starvation and one fed study period. There is no decrease in urea clearance during starvation. 
production by the fetus is directly related to the (a-A) urea difference:

$$
\left[\text { Urea production }_{\text {fetal }}=[\text { urea clearance }] \cdot[\mathrm{a}-\mathrm{A}]_{\text {urea }}\right.
$$

The animals fed the enriched protein diets (Table 2) had significantly higher absolute urea concentrations in both fetal and maternal blood when compared with animals on the usual protein intakes. However, there was no difference in the (a-A) urea differences between diet groups, and therefore no difference in fetal urea production rates, if we assume comparable urea clearances in the two groups. Thus, despite the higher maternal protein intake in one of the two groups, there was no evidence of increased amino acid catabolism by the fetus.

Figure 6 demonstrates that starvation had no deleterious effect on placental urea clearance. The observed increased (a-A) urea differences noted in starvation are therefore a result of increased urea production by the fetus. The peak of the increased urea production by the fetus (Fig. 5) occurs in the 4 th day of starvation, and by the 7 th day, urea production rates are not significantly different from fed state values.

Fetal glucose concentrations are remarkably stable after 48 hr of starvation (Fig. 4), following a significant fall $(\sim 35 \%)$ from fed state concentrations. The stability of the fetal glucose concentration is particularly striking in the face of the markedly depressed transplacental glucose uptakes (Fig. 7). From previous studies $(2,12)$ it is known that transplacental glucose uptake is related linearly to the (A-a) glucose differences. The significant decline in maternal glucose concentration induced by starvation (Fig. 3) leads to a corresponding reduction in glucose (A-a) differences (Fig. 5). The glucose (A-a) difference of $\sim 20 \mathrm{mg} / 100 \mathrm{ml}$ plasma water which we observed consistently throughout starvation implies a glucose uptake of $\sim 1.5 \mathrm{mg} / \mathrm{kg} / \mathrm{min}$ (Fig. 7), a rate only one-third of normal, yet still compatible with a surviving fetus and a stable fetal plasma glucose concentration. This study demonstrates that the initial fetal response to starvation is increased amino acid catabolism (and presumably gluconeogenesis) to adjust to the significantly decreased transplacental glucose supply.

Assuming for purposes of discussion an average placental urea clearance during starvation of $20 \mathrm{ml} / \mathrm{kg} / \mathrm{min}$, the maximal (a-A) urea difference which we observed during starvation reflects a urea production rate of approximately $2 \mathrm{mg} / \mathrm{kg} / \mathrm{min}$. The production of $2 \mathrm{mg}$ of urea requires the consumption of 6 $\mathrm{ml}$ oxygen (13), assuming the fetus was oxidizing an "average" amino acid mixture with $16 \%$ nitrogen. Thus, at the peak of starvation amino acid catabolism could account for most of fetal oxygen consumption, which approximates $6.5 \mathrm{ml} / \mathrm{kg} / \mathrm{min}$ in the starved state (2).

In man, increased amino acid catabolism is an important early response to starvation and appears to duplicate the time

Table 2. Effect of diet on glucose and urea levels ${ }^{1}$

\begin{tabular}{lccc}
\hline & Routine diet & $\begin{array}{c}\text { Enriched } \\
\text { protein diet }\end{array}$ & $P$ value \\
\hline Glucose $^{2}$ & & & \\
A & $71.11 \pm 6.46$ & $70.21 \pm 9.21$ & N.S. \\
a & $26.65 \pm 4.47$ & $26.17 \pm 2.57$ & N.S. \\
A-a & $44.51 \pm 4.38$ & $44.03 \pm 8.68$ & N.S. \\
Urea $^{2}$ & $30.23 \pm 10.27$ & $47.10 \pm 7.88$ & $<0.0005$ \\
a & $26.13 \pm 10.37$ & $42.77 \pm 7.64$ & $<0.0005$ \\
A & $4.10 \pm 1.64$ & $4.32 \pm 1.86$ & N.S. \\
a-A & & &
\end{tabular}

'a: fetal; A: maternal; N.S.: not significant.

${ }^{2} \mathrm{mg} / 100 \mathrm{ml} \pm \mathrm{SD}$.

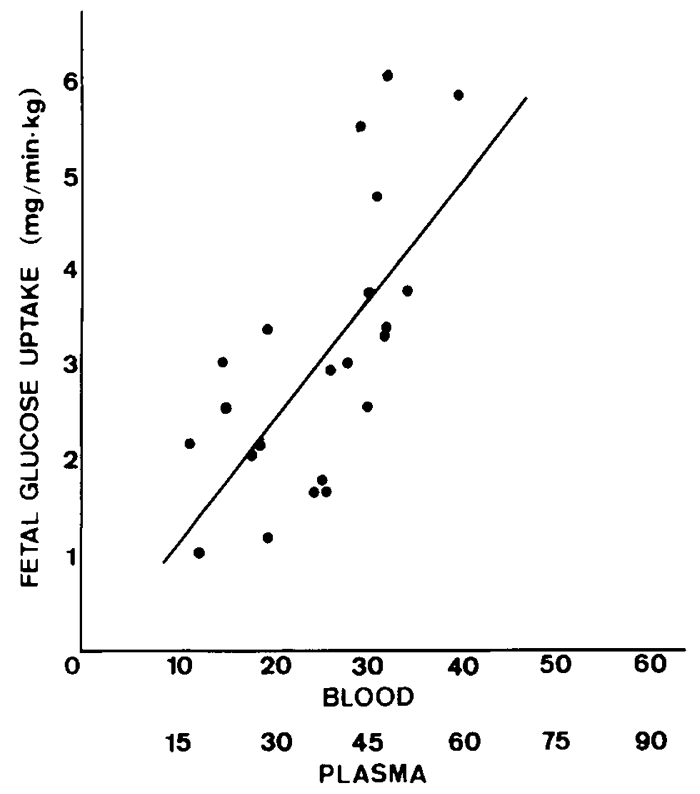

Fig. 7. Transplacental glucose uptakes by the fetus plotted against (maternal-fetal) glucose differences in milligrams per $100 \mathrm{ml}$. The figure is constructed on the basis of data by James et al. (12). Glucose concentrations in plasma are significantly higher than the whole blood determinations originally reported (12) and were calculated by simultaneous measurements of levels of glucose in plasma and whole blood in both fetal and maternal blood.

sequence demonstrated here in the fetal sheep (3). However, over prolonged starvation amino acid is largely spared and other mechanisms for glucose synthesis and conservation are required. Ballard and Oliver (1) have shown that the gluconeogenic pathway of fetal sheep liver (measured as pyruvate incorporation into glucose) is active by the 4th month of fetal life and that pyruvate incorporation rates increase fourfold by birth. Thus, the biochemical pathways to allow gluconeogenesis are well established in the sheep fetus by 120 days of gestation. The duration of the documented increase in amino acid catabolism is transient, however, and approximates quite closely the pattern in man during starvation (3). It is intriguing that even after prolonged starvation (up to 17 days) we never observed a fall in fetal urea production to below fed state levels, which would be anticipated from the data in adult man. This may reflect the large (relative to fetal size and requirements) maternal pool of protein potentially available for fetal homeostasis, a situation quite different from extrauterine life where the supply is endogenous, and thus limited, and its depletion carefully regulated.

Despite the significant growth retardation noted in all lambs, three of five lambs delivered at term survived, and all three survivors were normal to examination. Protein deprivation alone has been used to induce growth retardation (24), so it is not surprising that total caloric deprivation causes severe growth retardation.

Although it is clear that increased amino acid catabolism is the initial fetal adjustment to starvation, at least in the last month of gestation, fetal glucose concentration and transplacental glucose uptake (as reflected by glucose A-a) remain stable even after amino acid catabolism (urea production) returns to base line values. The substrates and mechanisms responsible for fetal homeostasis subsequently during continued starvation are unknown. In addition, the control over the early shift to amino acid catabolism and the origin of the amino acid supply, whether transplacental or from fetal tissues, are unknown. Both of these questions are currently under investigation. 


\section{SUMMARY}

The mechanisms of the fetal metabolic response to total maternal starvation were investigated in a chronic sheep preparation which allowed repeated sampling of fetal and maternal blood. Starvation was begun after a stable metabolic state was demonstrated in the fed state and lasted 6-17 days. In the surviving lambs, growth retardation was significant, but no other abnormalities were apparent.

Starvation caused a prompt fall in the concentration of glucose in blood in maternal and fetal blood over the first 48 $\mathrm{hr}$ of starvation, but a stable plateau of concentrations was reached after that time. Transplacental glucose uptake, as reflected by maternal fetal anterial concentration differences, also fell precipitously over the first $48 \mathrm{hr}$ and then stabilized throughout the remainder of the starvation period.

Urea production by the fetus increased over the first 4 days of starvation to a level twice that in the fed state and then returned to fed state levels by the 7 th day. The initial fetal metabolic response to maternal starvation is increased amino acid catabolism, and at the peak of starvation amino acid catabolism can account for most of fetal oxygen consumption. However, fetal glucose concentration remains stable even after urea production returns to fed state values. The substrates responsible for homeostasis after the 7 th day are currently unknown.

\section{REFERENCES AND NOTES}

1. Ballard, F. J., and Oliver, I. T.: Carbohydrate metabolism in liver from foetal and neonatal sheep. Biochem. J., 95: 191 (1965).

2. Boyd, R. D. H., Morriss, F. H., Jr., Meschia, G., Makowski, E. L., and Battaglia, F. C.: Growth of glucose and oxygen uptakes by fetuses of fed and starved ewes. Amer. J. Physiol., 225: 897 (1973).

3. Cahill, G. F., Jr., Herrera, M. G., Morgan, A. P., Soeldner, J. S., Steinke, J., Levy, P. L., Reichard, G. A., Jr., and Kipnis, D. M. Hormone-fuel interrelationships during fasting. J. Clin. Invest. 45: $1751(1966)$

4. Cahill, G. F., Jr., Owen, O. E., and Morgan, A. P.: The consumption of fuels during prolonged starvation. Advan. Enzyme Regul. 6: 143 (1968).

5. Dawes, G. S.: Foetal and Neonatal Physiology: A Comparative Study of the Changes at Birth, Ed. 1, p. 210 (Year Book Medical Publishers, Inc., Chicago, 1968).

6. Felig, P., Marliss, E., Owen, O. E., and Cahill, G. F., Jr.: Role of substrate in the regulation of hepatic gluconeogenesis in fasting man. Advan. Enzyme Regul. 7: 41 (1969).

7. Felig, P., Owen, O. E., Wahren, J., and Cahill, G. F., Jr.: Amino acid metabolism during prolonged starvation. J. Clin. Invest., 48 : 584 (1969).

8. Gresham, E. L., James, E. J., Raye, J. R., Battaglia, F. C. Makowski, E. L., and Meschia, G.: Production and excretion of urea by the fetal lamb. Pediatrics, 50: 372 (1972).

9. Gresham, E. L., Rankin, J. H. G., Makowski, E. L., Meschia, G. and Battaglia, F. C.: An evaluation of fetal renal function in a chronic sheep preparation. J. Clin. Invest., 51: 149 (1972).

10. Gresham, E. L., Simons, P. S., and Battaglia, F. C.: Maternal-fetal urea concentration difference in man: Metabolic significance. $J$.
Pediat., 79: 809 (1971).

11. James, E., Meschia, G., and Battaglia, F. C.: A-V differences of free fatty acids and glycerol in the ovine umbilical circulation. Proc. Soc. Exp. Biol. Med., 138: 823 (1971).

12. James, E. J., Raye, J. R., Gresham, E. L., Makowski, E. L. Meschia, G., and Battaglia, F. C.: Fetal oxygen consumption, carbon dioxide production, and glucose uptake in a chronic sheep preparation. Pediatrics, 50:361 (1972).

13. Kleiber, M.: Respiratory exchange and metabolic rate. In Handbook of Physiology, Vol. II: Respiration, p. 927 (American Physiological Society, Washington, D.C., 1965)

14. Lubchenco, L. O., Searls, D. T., and Brazie, J. V.: Neonata mortality rate: Relationship to birth weight and gestational age. J. Pediat., 81: 814 (1972).

15. McCance, R. A., and Widdowson, E. M.: Metabolism and renal function in the first two days of life. Cold Springs Harbor Symp. Quant. Biol., 19: 161 (1954).

16. Morriss, F. H., Jr., Meschia, G., Makowski, E. L., and Battaglia, F. C.: Umbilical glucose $/ \mathrm{O}_{2}$ quotient of the human fetus (Abstract). Pediat. Res., 7: 314 (1973).

17. Owen, O. E., Felig, P., Morgan, A. P., Wahren, J., and Cahill, G. F. Jr.: Liver and kidney metabolism during prolonged starvation. $J$ Clin. Invest., 48: 574 (1969).

18. Popjak, G., and Beeckmans, M.-L.: Synthesis of cholesterol and fatty acids in foetuses and in mammary glands of pregnant rabbits. Biochem. J., 46: 547 (1950).

19. Russel, A. J. F., Doney, J. M., and Reid, R. L.: The use of biochemical parameters in controlling nutritional states in pregnant ewes, and the effect of undernourishment during pregnancy on lamb birth weight. J. Agric. Sci. Camb., 68: 315, (1967)

20. Shelley, H. J.: The use of chronically catheterized foetal lambs for the study of foetal metabolism. In: Foetal and Neonata Physiology: Proceedings of the Sir Joseph Barcroft Centenary Symposium, Ed. 1, p. 360 (Cambridge University Press, Cambridge, 1973)

21. Tsoulos, N. G., Colwill, J. R., Battaglia, F. C., Makowski, E. L., and Meschia, G.: Comparison of glucose, fructose, and $\mathrm{O}_{2}$ uptakes by fetuses of fed and starved ewes. Amer. J. Physiol. 221: 234 (1971).

22. Van Duyne, C. M Parker, H. R, Havel, R, J, and Holm, L. W. Free fatty acid metabolism in fetal and newborn sheep. Amer. J. Physiol., 199: 987 (1960).

23. Van Duyne, C. M., Parker, H. R., and Holm, L. W.: Metabolism of free fatty acids during perinatal life of lambs. Amer. J. Obstet. Gynecol., 91: 277 (1965).

24. Wallace, L. R.: Growth of lambs before and after birth in relation to the level of nutrition. J. Agric. Sci., 38:93 (1948).

25. Albers Milling Co., Division of Carnation Co., Los Angeles, Calif.

26. Farmers' Marketing Association, Denver, Colo.

27. Beckman Instruments, Inc., Palo Alto, Calif.

28. American Optical, Buffalo, N.Y.

29. Tech

30. Dr. M. A. Simmons is supported by United States Public Health Service Special Postdoctoral Research Fellowship HD-53419.

31. This work was supported by United States Public Health Service Grants HD-00781 and HD-05111. Presented in part at the Annual Meeting of the American Pediatric Society, Society for Pediatric Research, San Francisco, California, May 19, 1973.

32. Requests for reprints should be addressed to F. C. Battaglia, M.D., Division of Perinatal Medicine, Container 2302, University of Colorado Medical Center, 4200 E. 9th Ave., Denver, Colo. 80220 (USA).

33. Accepted for publication June 10, 1974. 